\title{
Detection and molecular characterization of Trypanosoma (Duttonella) vivax in dairy cattle in the state of Sergipe, northeastern Brazil
}

Detecção e caracterização molecular de Trypanosoma (Duttonella) vivax em gado leiteiro no estado de Sergipe, no Nordeste do Brasil

\begin{abstract}
Osires Lustosa Eloi Vieira ${ }^{1}$; Lucia Oliveira de Macedo ${ }^{1}$; Marcos Antônio Bezerra Santos ${ }^{1}$; José Augusto Bastos Afonso Silva²; Carla Lopes de Mendonça²; Maria Aparecida da Gloria Faustino ${ }^{3}$; Carlos Alberto do Nascimento Ramos ${ }^{4}$; Leucio Câmara Alves ${ }^{3}$; Rafael Antonio Nascimento Ramos ${ }^{1}$; Gílcia Aparecida de Carvalho ${ }^{1 *}$
\end{abstract}

\author{
${ }^{1}$ Unidade Acadêmica de Garanhuns - UAG, Universidade Federal Rural de Pernambuco - UFRPE, Garanhuns, PE, Brasil \\ ${ }^{2}$ Clínica de Bovinos de Garanhuns, Universidade Federal Rural de Pernambuco - UFRPE, Garanhuns, PE, Brasil \\ ${ }^{3}$ Departamento de Medicina Veterinária, Universidade Federal Rural de Pernambuco - UFRPE, Recife, PE, Brasil \\ ${ }^{4}$ Faculdade de Medicina Veterinária e Zootecnia, Universidade Federal de Mato Grosso do Sul - UFMS, Campo Grande, MS, Brasil
}

Received July 19, 2017

Accepted August 22, 2017

\begin{abstract}
Trypanosoma (Duttonella) vivax is an important cause of economic losses among feedlot cattle. These losses are related to the morbidity, mortality, reproductive issues and decreased production. It is known that the clinical signs observed in infections by this protozoon are similar to other hemoparasitosis, which difficult the diagnosis. Therefore, the aim of this study was to detect and molecularly characterize an outbreak of trypanosomiasis caused by $T$. (D.) vivax in dairy cattle in the municipality of São Miguel Aleixo, state of Sergipe, Brazil. Blood samples from cattle $(n=15)$ presenting clinical signs compatible with trypanosomiasis were collected and parasitological and molecular evaluated. Among the samples analyzed, 34\% (5/15) were positive from blood smears, 60\% (9/15) from the buffy coat method and $80 \%(12 / 15)$ from the molecular method. The DNA sequence obtained (659 bp) showed $99 \%$ similarity to $T$. (D.) vivax sequences that are available in the GenBank database. The presence of this protozoon in cattle herds is a problem for producers. Diagnosing trypanosomiasis is problematic because its evolution is similar to that of other parasitic blood diseases. In addition, this is the first report of infection by $T$. (D.) vivax in cattle in the state of Sergipe, northeastern Brazil.
\end{abstract}

Keywords: Trypanosomiasis, parasitological diagnosis, molecular diagnosis.

\section{Resumo}

Trypanosoma (Duttonella) vivax é responsável por consideráveis perdas econômicas na bovinocultura. Estas perdas estão relacionados à morbidade, mortalidade, problemas reprodutivos e declínio na produção. Sabe-se que os sinais clínicos apresentados em infecçôes por este protozoário se assemelha a outras hemoparasitoses, dificultando muitas vezes o diagnóstico. Portanto, objetivou-se com este estudo detectar a ocorrência de $T$. (D.) vivax em bovinos leiteiros no município de São Miguel Aleixo, Estado de Sergipe, Brasil. Para tanto, amostras de sangue $(\mathrm{n}=15)$ foram coletadas e avaliadas através de métodos parasitológicos e moleculares. Do total das amostras analisadas, 34\% (5/15) foram positivas no esfregaço sanguíneo, 60\% (9/15) pelo método do Buffy Coat, enquanto na biologia molecular 80\% (12/15) amplificaram um fragmento de DNA $(659 \mathrm{pb})$ compatível com $T$. (D.) vivax (GenBank). Em conclusão a presença de T. (D.) vivax nos rebanhos bovinos caracteriza-se como um problema para os pecuaristas, como também para o diagnóstico, uma vez que essa tripanossomíase apresenta evolução semelhante a outras hemoparasitoses. Ademais, este é o primeiro relato de infecção por T. (D.) vivax em bovinos do estado de Sergipe, nordeste do Brasil.

Palavras-chave: Tripanossomíase, diagnóstico parasitológico, diagnóstico molecular.

*Corresponding author: Gílcia Aparecida de Carvalho. Unidade Acadêmica de Garanhuns - UAG, Universidade Federal Rural de Pernambuco - UFRPE,

Av. Bom Pastor, s/n, Boa Vista, CEP 55292-270, Garanhuns, PE, Brasil.

e-mail: gilcia.acarvalho@yahoo.com 


\section{Introduction}

Trypanosomiasis is a parasitic infection caused by protozoa belonging to the genus Trypanosoma, which affects domestic and wild mammals, including humans (GARDINER, 1989). Species such as Trypanosoma brucei, T. congolense, T. (Duttonella) vivax and T. evansi cause important economic losses in animal herds (HOARE, 1972), while T. cruzi is of public health importance, since it affects humans and dogs (DÁVILA \& SILVA, 2000).

Among the species that affect cattle, $T$. (D.) vivax is the most important from a pathogenic perspective. For example, in Africa this protozoon is of great importance in relation to livestock. Wild ungulates act as reservoirs, and flies of the genus Glossina act as vectors (BOWMAN, 2010). The adaptive capacity of this parasite has allowed it to acquire the ability to be transmitted mechanically by hematophagous dipterans (e.g. Tabanus spp., Stomoxys calcitrans and Haematobia irritans), which have caused the spread of trypanosomiasis to Central America, South America and the Caribbean (SILVA et al., 2003).

In Brazil, occurrences of $T$. (D.) vivax were reported for the first time in buffaloes in the state of Pará (SHAW \& LAINSON, 1972) and, over the last few years, it has been reported in other Brazilian states, such as Mato Grosso do Sul (PAIVA et al., 2000), Tocantins (LINHARES et al., 2006), Paraíba (BATISTA et al., 2007), Maranhão (GUERRA et al., 2008), Minas Gerais (CARVALHO et al., 2008; CUGLOVICI et al., 2010), Rio Grande do Sul (SILVA et al., 2009), Sáo Paulo (CADIOLI et al., 2012), Pernambuco (PIMENTEL et al., 2012) and recently in Goiás (BASTOS et al., 2017). Because of the possibility of mechanical transmission by flies of the family Tabanidae, Muscidae and Hippoboscidae (RADOSTITS et al., 2007), as well as iatrogenic transmission through use of shared needles and syringes, this protozoon has disseminated rapidly throughout the country.

It is known that cattle infected by this protozoon may present acute, chronic or asymptomatic forms of the disease (BOWMAN, 2010). The main clinical signs of trypanosomiasis are progressive weight loss, pale mucous membranes, decreased milk production, anorexia, hyperthermia (RADOSTITS et al., 2007) and neurological signs (BATISTA et al., 2007; GALIZA et al., 2011). Infection by $T$. (D.) vivax may be diagnosed via parasitological methods, in which the characteristics of the general structure of the blood forms are observed using optical microscopy; or via serological methods, i.e. the immunofluorescent antibody test (IFAT) and enzyme-linked immunosorbent assay (ELISA) (RADOSTITS et al., 2007); or via molecular methods. i.e. the polymerase chain reaction (PCR) (MADRUGA et al., 2006).

Considering the recent dispersion of T. (D.) vivax in Brazil and the economic impact that this protozoon may have, the aim of this study was to report and clinically, epidemiologically and molecularly characterize an outbreak of trypanosomiasis due to T. (D.) vivax in cattle in the state of Sergipe, northeastern Brazil.

\section{Materials and Methods}

\section{Study area and sample collection}

In August 2015, animals on a cattle farm in the municipality of São Miguel do Aleixo (10 23' 26" S and 37 22' 42” W), state of Sergipe, northeastern region of Brazil, presented with clinical signs relating to trypanosomiasis. Each animal was physically examined and clinical data reported in individual chart.

Blood samples were collected from the jugular vein of female lactating cattle $(\mathrm{n}=15)$ and the material collected was placed in $4 \mathrm{~mL}$ sterile tubes with EDTA anticoagulant. After parasitological processing, the remained blood was stored at $-20^{\circ} \mathrm{C}$ until molecular analysis.

\section{Laboratory analysis}

\section{Parasitological diagnosis}

The parasitological diagnosis was made via blood smears on microscope slides and via the buffy coat method (MURRAY et al., 1977). The slides were stained using the rapid panoptic method (Laborclin) and were observed under an optical microscope (40X and 100X). The parasitic structures found were measured using the AxioVision software (release 4.8). All measures and morphological analyses were based on previous studies (JOHNSON, 1941; SHAW \& LAINSON, 1972; OLIVEIRA et al., 2009).

\section{Molecular diagnosis}

Genomic DNA was extracted from $200 \mu \mathrm{l}$ of bovine blood using a commercial kit (Qiagen DNeasy blood and tissue kit; Hilden, Germany) following the manufacturer's recommendations. PCR was performed in accordance with the procedure described by Geysen et al. (2003), using the primers 18STnF2 (5-CAACGATGACACCCATGAATTGGGGA-3) and 18STnR3 (5-TGCGCGACCAATAATTGCAATAC-3), which amplified a fragment of 659 bp of the 18SrRNA gene of $T$. (D.) vivax. DNA samples from the blood of a naturally infected cow (PIMENTEL et al., 2012) and ultrapure DNase free water $\left(\mathrm{LGC}^{\circledR}\right)$ were used as positive and negative controls, respectively. The reaction of amplification was performed in the following conditions: 1 cycle of initial denaturation at $94{ }^{\circ} \mathrm{C}$ for 4 minutes, followed by 40 denaturation cycles at $94^{\circ} \mathrm{C}$ for 60 seconds, annealing at $58^{\circ} \mathrm{C}$ for 90 seconds, extension at $72^{\circ} \mathrm{C}$ for 120 seconds.

Randomly selected amplicons obtained from the positive samples were purified using the Qiaex II kit (Qiagen ${ }^{\circledR}$; Hilden, Germany) and were sequenced in both directions using the Sanger method (SANGER et al., 1977) in an automated sequencer ABI-3130 (Applied Biosystems). The identity of the DNA sequences was determined by comparison with sequences available in GenBank, using BLASTn (ALTSCHUL et al., 1990). A phylogenetic tree was constructed using the UPGMA method (SNEATH \& SOKAL, 1973). All sequences used in this study 
for construction of the phylogenetic tree were available in the GenBank database. Bootstrap resampling (1000 replicates) was performed for statistical support regarding the reliabilities of the nodes on the trees (FELSENSTEIN, 1985) using the MEGA software, version 6.0 (TAMURA et al., 2013).

\section{Data analysis}

The statistical analysis to assess the parasitological methods was performed through the Fisher exact test using the BioEstat 5.0 software (AYRES et al., 2000).

\section{Results}

Out of the total of 15 lactating cows examined, 20\% (3/15) presented hyperthermia, decreased milk production, anorexia, apathy, pale mucous membranes, tachycardia, tachypnea, dehydration and enophthalmos. Of these, 6.7\% (1/15) presented neurological signs, including incoordination, muscle tremors, hypermetria and dysmetria. In addition, a high number of cases of abortion

Table 1. Biometric mean and standard deviation $(\mu \mathrm{m})$ of the number of specimens of Trypanosoma (Duttonella) vivax observed in blood smears from naturally infected cattle.

\begin{tabular}{lr}
\hline & \multicolumn{1}{c}{$\mathbf{X} \pm \mathbf{S D}$} \\
\hline Total lenght, including flagellum & $22.55 \pm 1.81$ \\
Distance from the kinetoplast to the posterior region & $1.18 \pm 0.38$ \\
Distance from the nucleus to the kinetoplast & $4.76 \pm 0.29$ \\
Distance from the posterior region to the nucleus & $5.78 \pm 0.30$ \\
Distance from the anterior region to the nucleus & $8.08 \pm 0.62$ \\
Free flagellum & $7.61 \pm 0.94$ \\
\hline
\end{tabular}

$(33.34 \% ; 5 / 15)$ was observed among the animals that were studied on this farm, along with a high number of deaths $(20 \% ; 3 / 15)$.

Through the laboratory analysis, the protozoon was detected in $34 \%(5 / 15)$ of the blood smears and $60 \%(9 / 15)$ of the buffy coat. There was no statistical difference between the parasitological methods $(\mathrm{p}=0.0420)$. The protozoon was morphologically and morphometrically identified as $T$. (D.) vivax (Table 1 ).

In the molecular analysis on the bovine blood samples, $80 \%(12 / 15)$ were positive for a fragment $(659 \mathrm{bp})$ with $99 \%$ similarity to T. vivax sequences available from GenBank (accession numbers KM391829, KM391827, KM391826, HM209400, KM391823 and AY362546). The sequence obtained in the present study was deposited in GenBank under accession number KX766453.

In the phylogenetic analysis, the isolates of $T$. (D.) vivax clustered separately from other Trypanosoma species ( $T$. congolense and T. evansi). This was supported by a high bootstrap value (Figure 1).

\section{Discussion}

This study detected for the first time the infection due to $T$. (D.) vivax in dairy cattle in the state of Sergipe, Brazil. Although infection due to $T$. (D.) vivax does not present with specific clinical signs, some signs described here are compatible with those already reported in the scientific literature (LINHARES et al., 2006; FIDELIS et al., 2016). Interestingly, one animal presented neurological signs that were consistent with reports from an outbreak of T. (D.) vivax in cattle in the Brazilian semiarid region (BATISTA et al., 2007). There have also been reports of abortion on the farm evaluated here, similar to the findings of higher numbers of cases in the state of Pernambuco in cows infected by T. (D.) vivax (PIMENTEL et al., 2012). In addition, a mortality rate of $20 \%$ was observed here, among the positive animals.

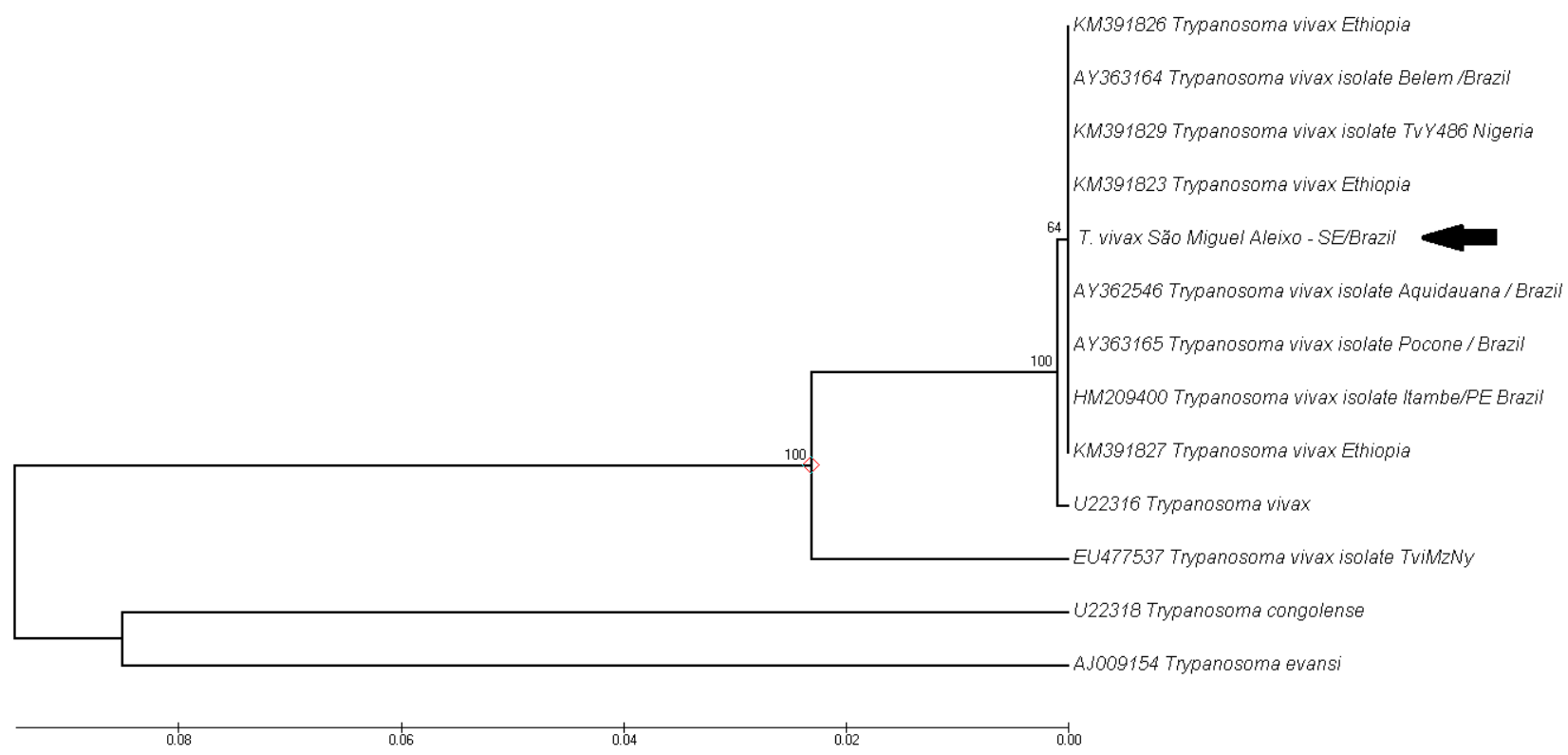

Figure 1. Phylogenetic tree based on Trypanosoma vivax 18SrRNA gene sequences. Sequences were compared using the UPGMA method. The percentage of replicate trees in which the associated taxa clustered together in the bootstrap test (1000 replicates) are shown next to the branches. The scale bar represents the number of mutations per sequence position. 
The rate of positive parasitological diagnosis was lower than the rate observed via the molecular method. Although the parasitological method presents low sensitivity, it is known to be commonly used in several parts of the world to diagnose infections due to $T$. (D.) vivax (MADRUGA et al., 2006). However, parasitological techniques present low sensitivity in the chronic phase, whereas in the acute phase the sensitivity is higher depending on the parasitemia level (MADRUGA et al., 2006).

In the present study, the molecular diagnosis (PCR) on the samples analyzed showed a positivity rate of $80 \%(12 / 15)$ for $T$. (D.) vivax. This rate was lower than what was previously reported in the northeast region, in which $100 \%(22 / 22)$ of the animals were positive (PIMENTEL et al., 2012). The primers used in the present study amplify fragments of lengths of between 700 and 800 bp, depending on the species of Trypanosoma involved (GEYSEN at al., 2003). Using the same primers, Madruga et al. (2003) found that the fragment amplified was $659 \mathrm{bp}$ in Brazilian samples of $T$. (D.) vivax. Therefore, the amplicons obtained in the present study were compatible in size to the ones described for Brazilian isolates of T. (D.) vivax. Thus, it can be concluded that PCR is a sensitive method for detection of T. (D.) vivax, which results in higher confidence in the diagnosis of trypanosomiasis.

In this report on $T$. (D.) vivax on a farm in São Miguel do Aleixo, the histories of the cattle involved showed that the first cases occurred after animals had been purchased and introduced from farms that traded in animals from other states. This suggests that the protozoon was introduced through acquisition of animals without previous knowledge of their health status. Another important factor is that on the farm studied here, oxytocin was administered intravenously to the cows every day before milking, using the same needle and syringe for all animals. Therefore, iatrogenic transmission seems to be the most important factor regarding the spread of T. (D.) vivax among these animals. After confirmation of the diagnosis of infection due to $T$. (D.) vivax, the farmer's attention was drawn to this, to avoid this form of transmission, especially regarding the need to avoid sharing of needles between animals.

In conclusion, presence of $T$. (D.) vivax in cattle herds is problem for livestock producers. Diagnosing trypanosomiasis is problematic because its evolution is similar to that of other parasitic blood diseases. Therefore, close attention to transit of animals from regions where the parasite is present is needed, along with care and clarification regarding the risks of sharing needles, in order to avoid economic losses associated with infection caused by this protozoon.

\section{Acknowledgements}

The authors would like thank Bronwyn Campbell (University of Bari, Italy) for her suggestions regarding the manuscript.

\section{References}

Altschul SF, Gish W, Miller W, Myers EW, Lipman DJ. Basic local alignment search tool. J Mol Biol 1990; 215(3): 403-410. PMid:2231712. http://dx.doi.org/10.1016/S0022-2836(05)80360-2.
Ayres M, Ayres M Jr, Ayres DL, Santos AL. BioEstat 2.0: aplicaçōes estatísticas nas áreas das ciências biológicas e médicas. Brasília: Sociedade Civil Mamirauá, CNPq; 2000. 272 p.

Bastos TSA, Faria AM, Madrid DMC, Bessa LC, Linhares GFC, Fidelis OLJ Jr, et al. First outbreak and subsequent cases of Trypanosoma vivax in the state of Goias, Brazil. Rev Bras Parasitol Vet 2017; 0. http://dx.doi. org/10.1590/S1984-29612017019. PMid:28678894.

Batista JS, Riet-Correa F, Teixeira MMG, Madruga CR, Simôes SDV, Maia TF. Trypanosomiasis by Trypanosoma vivax in cattle in the Brazilian semiarid: description of an outbreak and lesions in the nervous system. Vet Parasitol 2007; 143(2): 174-181. PMid:16965857. http://dx.doi. org/10.1016/j.vetpar.2006.08.017.

Bowman D. Georgis: parasitologia veterinária. 9th ed. Rio de Janeiro: Elsevier; 2010. 448 p.

Cadioli FA, Barnabé PA, Machado RZ, Teixeira MCA, André MR, Sampaio $\mathrm{PH}$, et al. First report of Trypanosoma vivax outbreak in dairy cattle in São Paulo State, Brazil. Rev Bras Parasitol Vet 2012; 21(2): 118-124. PMid:22832751. http://dx.doi.org/10.1590/S1984-29612012000200009.

Carvalho AU, Abrão DC, Facury EJ Fo, Paes PRO, Ribeiro MFB. Ocorrência do Trypanosoma vivax no estado de Minas Gerais. Arq Bras Med Vet Zootec 2008; 60(3): 769-771. http://dx.doi.org/10.1590/S010209352008000300037.

Cuglovici DA, Bartholomeu DC, Reis-Cunha JL, Carvalho AU, Ribeiro MFB. Epidemiologic aspects of an outbreak of Trypanosoma vivax in a dairy cattle herd in Minas Gerais state, Brazil. Vet Parasitol 2010; 169(3-4): 320-326. PMid:20138431. http://dx.doi.org/10.1016/j. vetpar.2009.12.041.

Dávila AMR, Silva RAMS. Animal Trypanosomiasis in South America: Current Status, Partnership, and Information Technology. Ann $N$ $Y$ Acad Sci 2000; 916(1): 199-212. PMid:11193622. http://dx.doi. org/10.1111/j.1749-6632.2000.tb05291.x.

Felsenstein J. Confidence limits on phylogenies: an approach using the bootstrap. Evolution 1985; 39(4): 783-791. PMid:28561359. http:// dx.doi.org/10.1111/j.1558-5646.1985.tb00420.x.

Fidelis OL Jr, Sampaio PH, Machado RZ, Andre MR, Marques LC, Cadioli FA. Evaluation of clinical signs, parasitemia, hematologic and biochemical changes in cattle experimentally infected with Trypanosoma vivax. Rev Bras Parasitol Vet 2016; 25(1): 69-81. PMid:27007249. http:// dx.doi.org/10.1590/S1984-29612016013.

Galiza GJN, Garcia HA, Assis ACO, Oliveira DM, Pimentel LA, Dantas AFM, et al. High mortality and lesions of the central nervous system in Trypanosomosis by Trypanosoma vivax in Brazilian hair sheep. Vet Parasitol 2011; 182(2-4): 359-363. PMid:21664764. http://dx.doi. org/10.1016/j.vetpar.2011.05.016.

Gardiner PR. Recent studies of the biology of Trypanosoma vivax. Adv Parasitol 1989; 28: 229-317. PMid:2683616. http://dx.doi.org/10.1016/ S0065-308X(08)60334-6.

Geysen D, Delespaux V, Geerts S. PCR-RFLP using Ssu-rDNA amplification as an easy method for species-specific diagnosis of Trypanosoma species in cattle. Vet Parasitol 2003; 110(3-4): 171-180. PMid:12482646. http:// dx.doi.org/10.1016/S0304-4017(02)00313-8.

Guerra RMSNC, Feitosa Júnior AB, Santos HP, Abreu-Silva AL, Santos ACG. Biometry of Trypanosoma vivax found in a calf in the state of Maranhão, Brazil. Cienc Rural 2008; 38(3): 833-835. http://dx.doi. org/10.1590/S0103-84782008000300041. 
Hoare CA. The trypanosomes of mammals: a zoological monograph. Blackwell Scientific Publications; 1972.

Johnson CM. Bovine trypanosomiasis in Panama. Am J Trop Med Hyg 1941; 21(2): 289-297. http://dx.doi.org/10.4269/ajtmh.1941.s1-21.289.

Linhares GFC, Dias FC Fo, Fernandes PR, Duarte SC. Tripanossomíase em bovinos no município de Formoso do Araguaia, Tocantins. Cienc Anim Bras 2006; 7(4): 455-460.

Madruga CR, Araújo FR, Lima MSC Jr, Melo ESP. Comparação de métodos de extração do DNA e avaliação de reaçōes da polimerase em cadeia (PCR) para o diagnóstico de Trypanosoma (Duttonella) vivax. Campo Grande: Embrapa Gado de Corte; 2006. vol. 34. Circular Técnica.

Madruga CR, Araújo FR, Soares CO, Melo ESP, Almeida DA, Almeida NF Jr, et al. Diagnóstico molecular e análise filogenética de isolados brasileiros de Trypanosoma vivax baseado na reação da polimerase em cadeia - PCR. Campo Grande: Embrapa Gado de Corte; 2003. vol. 84. Comunicado Técnico.

Murray M, Murray PK, McIntyre WIM. An improved parasitological technique for the diagnosis of African trypanosomiasis. Trans $R$ Soc Trop Med Hyg 1977; 71(4): 325-326. PMid:563634. http://dx.doi. org/10.1016/0035-9203(77)90110-9.

Oliveira JB, Hernández-Gamboa J, Jiménez-Alfaro C, Zeledón R, Blandón M, Urbina A. First report of Trypanosoma vivax infection in dairy cattle from Costa Rica. Vet Parasitol 2009; 163(1-2): 136-139. PMid:19414224. http://dx.doi.org/10.1016/j.vetpar.2009.03.051.

Paiva F, Lemos RA, Nakasato L, More AE, Brum KB, Bernardo KC. Trypanosoma vivax em bovinos no Pantanal do Estado do Mato Grosso do Sul, Brasil: I - Acompanhamento clínico, laboratorial e anatomopatológico de rebanhos infectados. Rev Bras Parasitol Vet 2000; 9(2): 135-141.
Pimentel DS, Ramos CAN, Ramos RAN, Araújo FR, Borba ML, Faustino MAG, et al. First report and molecular characterization of Trypanosoma vivax in cattle from state of Pernambuco, Brasil. Vet Parasitol 2012; 185(2-4): 286-289. PMid:22054681. http://dx.doi.org/10.1016/j. vetpar.2011.10.019.

Radostits OM, Gay CC, Hinchcliff KW, Constable PD. Veterinary medicine: a textbook of the diseases of cattle, horses, sheep, pigs and goats. 10th ed. Edinburg: Saunders; 2007.

Sanger F, Nicklen S, Coulson AR. DNA sequencing with chain-terminating inhibitors. Proc Natl Acad Sci USA 1977; 74(12): 5463-5467. PMid:271968. http://dx.doi.org/10.1073/pnas.74.12.5463.

Shaw JJ, Lainson R. Trypanosoma vivax in Brasil. Trop Med Parasitol 1972; 66(1): 25-32. PMid:5021570. http://dx.doi.org/10.1080/0003 4983.1972.11686794.

Silva AS, Costa MM, Polenz MF, Polenz CH, Teixeira MMG, Lopes STA, et al. Primeiro registro de Trypanosoma vivax em bovinos no Estado do Rio Grande do Sul, Brasil. Cienc Rural 2009; 39(8): 2550-2554. http://dx.doi.org/10.1590/S0103-84782009005000189.

Silva RAMS, Sanchez V, Dávila AMR. Métodos de diagnósticos parasitológicos das tripanosomoses bovinas e equinas. Corumbá: Embrapa Pantanal; 2003. vol. 41. Circular Técnica.

Sneath PHA, Sokal RR. Numerical taxonomy: the principles and practice of numerical classification. San Francisco: Freeman; 1973.

Tamura K, Stecher G, Peterson D, Filipski A, Kumar S. MEGA6: molecular evolutionary genetics analysis version 6.0. Mol Biol Evol 2013; 30(12) 2725-2729. PMid:24132122. http://dx.doi.org/10.1093/molbev/mst197. 